\title{
A teratological case in the family Idiostolidae (Hemiptera: Heteroptera: Idiostoloidea)
}

\author{
Un caso teratológico en la familia Idiostolidae \\ (Hemiptera: Heteroptera: Idiostoloidea)
}

Mariom A. Carvajal1,2 \& Eduardo I. Faúndez ${ }^{1,2}$

\begin{abstract}
A teratosis is described for the first time in the family Idiostolidae; more specifically a female of Idiostolus insularis (Berg, 1881). The specimen was collected in Punta Arenas, Magallanes Region, Chile. The malformation is classified as an oligomery in the right antennae, and it is believed that it was caused probably due regeneration after an injury during an early instar.
\end{abstract}

\section{Key words:}

Idiostolus insularis, Teratology, antennal malformation, South America.

\section{Resumen}

Se describe por primera vez una teratosis en la familia Idiostolidae, específicamente en una hembra de Idiostolus insularis (Berg, 1881) recolectada en Punta Arenas, Región de Magallanes, Chile. La malformación se clasifica como una oligomeria en la antena derecha, y se cree que fue causada por alguna herida o trauma durante algún instar previo.

\section{Palabras clave:}

Idiostolus insularis, Teratología, malformación antenal, Sudamérica.

\section{INTRODUCTION}

The Idiostolidae Scudder, 1962, commonly known as transantarctic bugs, are a Heteropteran family which comprises five species in three genera. Idiostolids inhabit the southern hemisphere, having a classical Gondwanian distribution (Schaefer \& Wilcox, 1969). Little is known about the biology of transantarctic bugs (Schaefer \& Wilcox, 1969), which are believed to be inhabitants of mosses and litter associated with Nothofagus Blume (Nothofagaceae) forests (Schuh \& Slater, 1995). In South America, Idiostolidae is represented by two species, both on the genus Idiostolus (Faúndez et al, 2014). Idiostolus insularis (Berg, 1881) is the widest distributed species of this genus. It is present in Southern Chile and Argentinean Patagonia, reaching latitudes where the weather conditions are unfavorable for most Heteropterans (Carvajal \& Faúndez, 2011).

Teratology is the study of malformations and abnormalities; in a more colloquial language, it is known as the study of the monsters and semimonsters (Dallas, 1926; Perez D'Angello, 1967). Teratosis are singular facts which occur on individuals, influencing on its ontogeny. However, in some cases these facts can last on the time, and on the phylogeny of a determined linage (Ortuño \& Ramos, 2008).

For the Heteroptera, the major contributions on this field are those of Balazuc (1951) and Štusak \& Stelihk (1977, 1978, 1979, 1980, 1982); however, there are few reports regarding Chilean Heteropterans (Faúndez \& Rocca, 2016).

1 Entomology Department, School of Natural Resource Sciences, North Dakota State University, Dept. 7650, P.O. Box 6050; Fargo, ND, USA.

$\sum$ mariom.carvajal@gmail.com

2 Departamento de Zoología Médica, Centro de Estudios en Biodiversidad (CEBCh), Magallanes, 1979, Osorno, Chile. 
The purpose of this contribution is to describe a teratological specimen of Idiostolus insularis from the Magallanes Region.

\section{MATERIALS AND METHODS}

In terminology and teratological classification we follow Balazuc (1951) and Štusak \& Sthelik (1978). Photos were taken with a digital camera adapted to a stereoscopic microscope. All measurements are expressed in millimeters.

\section{RESULTS}

Oligomery in right antenna of Idiostolus insularis (Berg, 1881) (Figures 1-3)
In the present case the left antenna of the adult specimen is normal, having 4 segments (Table I; Fig. 1). On the other hand, the right antenna has only 3 segments, which have different size proportions compared to the first 3 segments in the normal antenna (Fig. 3; Table I). In the teratologic antenna the first antennomere is shorter and thicker than the normal antenna (Fig. 2); the second antennomere, although it has the same color pattern and shape (Fig. 2), is longer than in the normal one (Fig 3). The third antennomere in the right antenna is longer than its left counterpart (Table I), and it has similar shape and color pattern as the fourth antennomere in the normal antenna (Figs. 1, 3).

Material examined: Chile, Magallanes,
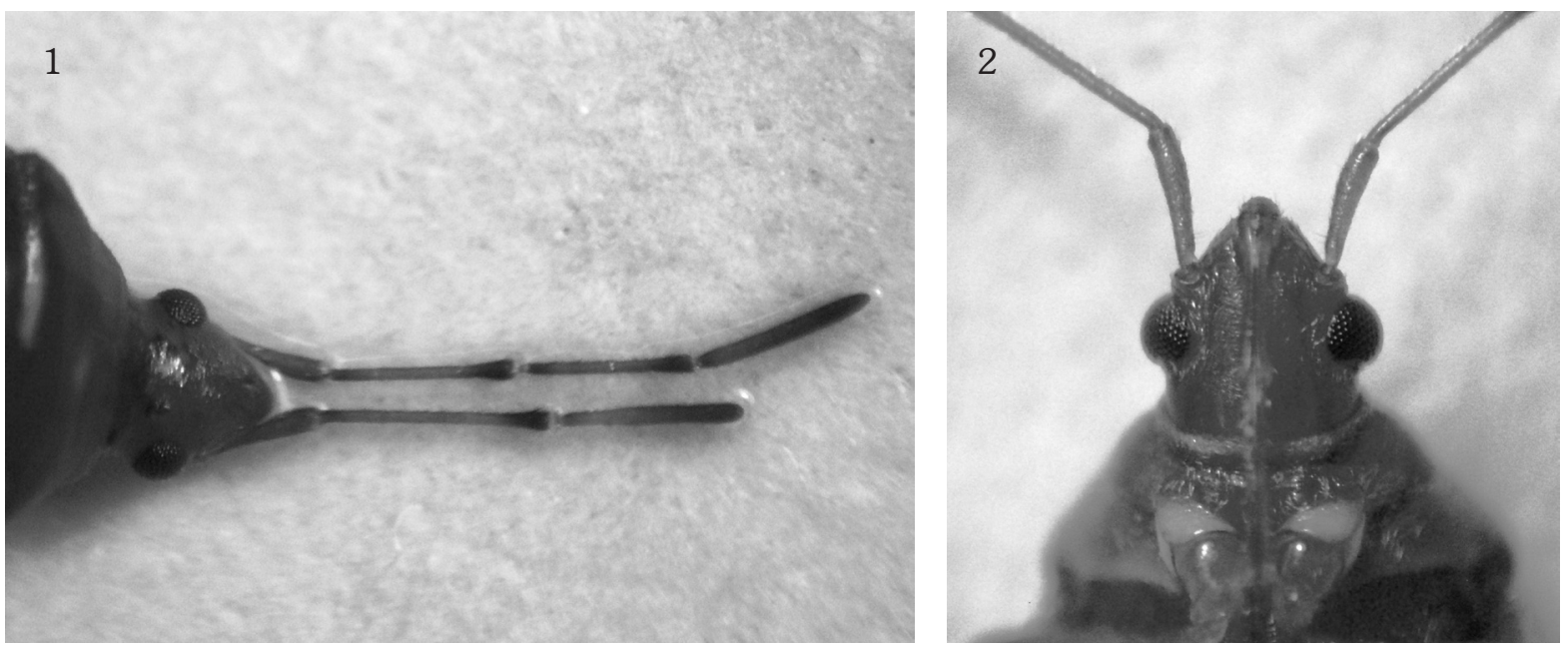

Fig. 1. Teratological specimen of Idiostolus insularis, left and right antennae, dorsal view; Fig. 2. Teratological specimen of Idiostolus insularis, detailed view of left and right first antennomere.

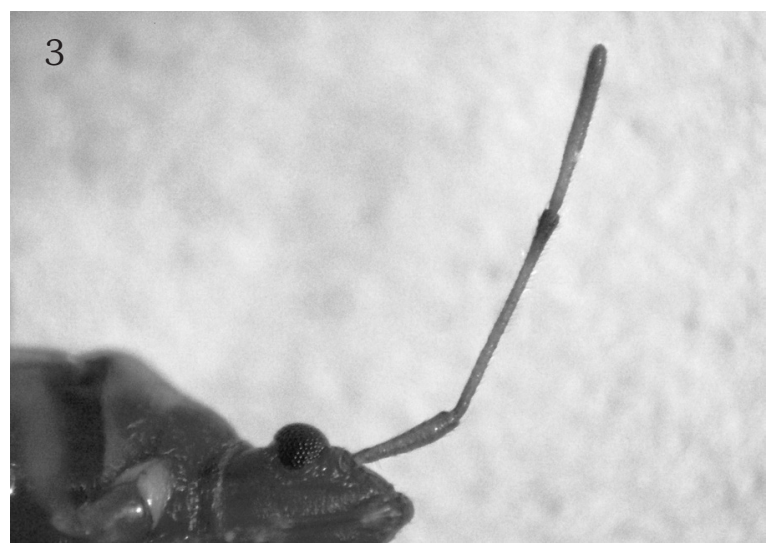

Fig. 3. Teratological specimen of Idiostolus insularis, detail of right antenna, ventral view.
20-I-2011, Jardín Botánico Carl Skottsberg, Instituto de la Patagonia, Carvajal \& Faúndez leg, 1 , , on Nothofagus antarctica (Mirb.) Oerst (Nothofagaceae). (Deposited in the Heteroptera Reference Collection of the Centro de Estudios en Biodiversidad, HRCC).

\section{DISCUSSION AND CONCLUSIONS}

The teratologic specimen in this work presents an oligomery, where the fourth segment of the right antenna has been lost. Oligomeries as defined by Štusak \& Stelihk (1978) are the reduction in the number of segments; and usually are due to injury in early life stages. For this 
Table I. Antennal measurements of the Idiostolus insularis teratological specimen.

\begin{tabular}{lccccc}
\hline Antennomere & I & II & III & IV & Total \\
\hline Left antenna & 0.71 & 1.05 & 0.96 & 1.14 & 3.86 \\
Right antenna & 0.59 & 1.33 & 1.06 & - & 2.98 \\
\hline
\end{tabular}

case, the loss of the fourth segment could be due to injury during the molting process, giving place for regeneration before reaching the adult stage. According to Štusak \& Stelihk (1978), the generation of bigger or more developed segments following the malformation, like in the present case, is influenced by the loss of the segment itself, as a way to compensate the losing. On this way, it is also common that the terminal regenerated segment acquires characteristics of the last segment to avoid missing some sensorial properties of the last antennomere (Štusak \& Sthelik, 1978); which appeared to happen on this case (Fig. 3). Furthermore, this anomaly can also be classified as a simple oligomery, where no anarthrogenesis can be observed, and acquirement of function by the substituting segments is possible. This kind of teratosis have been observed for other heteropterans (Stusak \& Sthelik, 1978; Balazuc, 1951); especially in Lygaeidae and affine groups, where antennal teratosis are the most common (Costas et al., 1992). However, no previous cases are known for the family Idiostolidae. In Chile Heteropteran antennal malformations have been described for an Acanthosomatid (Faúndez \& Carvajal, 2011); a Pentatomid (Faúndez \& Lüer, 2015); and a Lygaeid (Faúndez \& Rocca, 2016), becoming this report the fourth case of an antennal teratosis on a Chilean Heteropteran.

\section{LITERATURE CITED}

Balazuc, J. (1951). La tératologie des Hémiptères et groupes voisins. Annales de la Société entomologique de France, 120, 17-66.

Carvajal, M. A. \& Faúndez, E. I. (2011). Notes on the distribution of Idiostolus insularis Berg, 1881 (Hemiptera: Heteroptera: Idiostolidae). Boletín de Biodiversidad de Chile, 6,30-32.

Costas, M. López, T., \& Vázquez, M. A. (1992). Teratologías en Lygaeidae (Heteroptera).
Actas do $V$ Congreso Ibérico de Entomología, Lisboa, 1992 vol I, 313-322. Dallas, E. D. (1926). Anomalías en coleópteros chilenos. Revista Chilena de Historia Natural, 30, 73-83.

Faúndez, E. I., \& Carvajal, M. A. (2011). Un caso teratológico en un ejemplar de Ditomotarsus punctiventris Spinola, 1852 (Hemiptera: Heteroptera: Acanthosomatidae) de Magallanes (Chile). Boletín de la Sociedad Entomológica Aragonesa, 48, 431-432.

Faúndez, E. I., \& Lüer, A. (2015). A teratologic case in Oenopiella punctaria (Stål, 1859) (Heteroptera: Pentatomidae: Pentatominae: Carpocorini) from the Aisén region (Chile). Anales del Instituto de la Patagonia, 43(1), 153-156.

Faúndez, E. I., \& Rocca, J. R. (2016). Descripción de un caso teratológico en Oncopeltus (Erythrischius) miles (Blanchard, 1852) (Heteroptera: Lygaeidae) con notas acerca de su distribución y biología. Arquivos Entomolóxicos, 15, 39-43.

Faúndez, E. I., Carvajal, M. A., \& Ashworth A. C. (2014). Una nueva especie de Idiostolus Berg, 1883 (Hemiptera: Heteroptera: Idiostoloidea: Idiostolidae). Anales del Instituto de la Patagonia, 42(1), 71-75.

Ortuño, V. M., \& Ramos Abuin, J. A. (2008). Reflexiones sobre la teratología y descripciones de cuatro teratosis apendiculares en Coleoptera. Boletin Sociedad Entomológica Aragonesa, 43, 435-439.

Pérez D’Angello, V. (1967). Contribución a la entomoteratología. Noticiario Mensual del Museo Natural de Historia Natural, 11(129), 4 pp.

Schaefer, C. W., \& D. Wilcox. (1969). Notes on the Morphology, Taxonomy, and Distribution of the Idiostolidae (Hemiptera-Heteroptera). Annals of the Entomological Society of America, 62(3), 485-502. 
Schuh, R. T., \& Slater, J. A. (1995). True bugs of the World (Hemiptera: Heteroptera): Classification and Natural History. Cornell University Press, Ithaca, New York.

Štusak, J. M., \& Sthelik, J. L. (1977). First contribution to the teratology of Tingidae (Heteroptera) reflexion and variability of paranota. Acta Musei Moraviae, Scientiae biologicae, 62, 119-122.

Štusak J. M., \& Sthelik, J. L. (1978). Second contribution to the teratology of Tingidae (Heteroptera) Antennal anomalies. Acta Musei Moraviae, Scientiae biologicae, 63, 89-105.

Štusak J. M., \& Sthelik, J. L. (1979). Third contribution to the teratology of Tingidae (Heteroptera) Anomalies of legs. Acta Musei Moraviae, Scientiae biologicae, 64, 75-84.

Štusak J. M., \& Sthelik, J. L. (1980) Fourth contribution to the teratology of Tingidae (Heteroptera). Anomalies of head and thorax. Acta Musei Moraviae, Scientiae biologicae, 65, 161-172.

Štusak J. M., \& Sthelik, J. L. (1982). Fifth contribution to the teratology of Tingidae (Heteroptera). Anomalies of fore wings (Hemelytra). Acta Musei Moraviae, Scientiae biologicae, 67, 163-180. 